\title{
KESESUAIAN PENGAJARAN SASTRA DALAM BUKU TEKS KELAS X KURIKULUM 2013 MENUJU ABAD 21: PERSPEKTIF PENGAJARAN SASTRA MOODY
}

\author{
Rudi Umar Susanto \\ rudio@unusa.ac.id \\ Universitas Nahdlatul Ulama Surabaya, Indonesia
}

\begin{abstract}
In applying the principles of learning implementation in the perspective of literature appreciation, the principles in literaturelearning have a purpose as a means of increasing sensitivity to love for the culture of the Indonesian nation. In addition, literature learning can provide spiritual satisfaction and understanding in language. Literature learning is not merely a lesson of history, flow, and literature theory but the implementation of all these elements. Broadly speaking, the focus in literature learning can be seen through two aspects. This will give an idea as to what forms of literature appreciation learning in the present. This focus can be seen in general and implementation at the curriculum level in each school. In general, the purpose of learning in the perspective of literature aims for students to gain new experiences in enjoying a literature work and obtain knowledge in a literature work. Literature work is an embodiment of the essence of a reality that is inscribed in a work. This paper explores the correlation between the relationship of literature teaching in class X curriculum textbook 2013 to the 21st century: perspective of moody literature teaching. In addition, there is a readiness in covering a weakness in every implementation of literature and language learning. In the implementation in the world of education, especially language and literature learning in the current era of globalization, the need for signs or rules to apply the appropriate rules, this aims as a concern for every teacher.
\end{abstract}

Keywords: literature teaching, textbooks, 21st century, moody's approach

\section{ABSTRAK}

Dalam penerapan prinsip implementasi pembelajaran dalam perspektif apresiasi sastra, prinsip-prinsip dalam pembelajaran sastra memiliki tujuan sebagai sarana untuk peningkatan kepekaan terhadap cinta terhadap budaya bangsa Indonesia. Selain itu, pembelajaran sastra dapat memberikan kepuasan rohani serta pemahaman niali dalam berbahasa. Pembelajaran sastra bukan semata-matapelajaran sejarah, aliran, dan teori sastra melainkan implementasi dari kesemua unsur tersebut. Secara garis besar, fokus dalam pembelajaran sastra dapat dilihat melalui dua aspek. Hal ini akan memberikan gambaran seperti apa wujud pembelajaran apresiasi sastra di masa kini. Fokus tersebut dapat dilihat secara umum maupun secara implementasi di tingkat kurikulum yang ada di setiap sekolah. Secara umum tujuan pembelajaran dalam perspektif sastra bertujuan agar siswa dalam memperoleh pengalaman baru dalam menikmati sebuah karya sastra serta memperoleh sebuah pengetahuan dalam karya sastra. Karya sastra merupakan perwujudan dari esensi sebuah kernyataan yang ditorehkan dalam sebuah karya. Tulisan ini menggali korelasi antara hubungan pengajaran sastra dalam buku teks kelas X kurikulum 2013 menuju abad 21: perspektif pengajaran sastra moody. Selain itu, adanya kesiapan dalam menutupi sebuah kelemahan dalam setiap pelaksanaan pembelajaran sastra dan bahasa. Dalam implementasi di dunia pendidikan khususnya pembelajaran bahasa dan sastra di era globalisasi saat ini, perlunya sebuah rambu-rambu atau aturan untuk menerapkan kaidah-kaidah yang sesuai, hal ini bertujuan sebagai perhatian bagi setiap guru.

Kata Kunci: pengajaran sastra, buku teks, abad 21, pendekatan moody

\begin{tabular}{|c|c|c|}
\hline Submitted & Accepted & Published \\
\hline 11 Juli 2019 & 14 September 2019 & 13 November 2019 \\
\hline
\end{tabular}

\begin{tabular}{|l|c|r|r|}
\hline Citation & $:$ & $\begin{array}{r}\text { Susanto, R.U. (2019). Kesesuaian Pengajaran Sastra dalam Buku Teks Kelas X Kurikulum 2013 Menuju Abad 21: } \\
\text { Perspektif Pengajaran Sastra Moody. Jurnal PAJAR (Pendidikan dan Pengajaran), 3(6), 1273-1281. DOI : } \\
\text { http://dx.doi.org/10.33578/pjr.v3i6.7620. }\end{array}$ \\
\hline
\end{tabular}

\section{PENDAHULUAN}

Hakikat sebuah karya sastra merupakan bentuk representasi keadaan sosial budaya di masyarakat. Pada dasarnya karya sastra bukanlah ilmu yang mengupas secara konkret seperti pada bidang ilmu-ilmu eksakta. Jika membahas karya sastra tidak lepas dengan istilah sastra. Sastra merupakan cabang seni. Membahas tentang seni, tidak lepas campur tangan manusia dan beserta penafsirannya. Aspek penafsiran ini meliputi masalah perasaan, semangat, dan kepercayaan 
dari para penikmat karya sastra. Dilihat dari pengantar di atas, sastra mempunyai cakupan amat luas dalam kaidah implementasinya, namun semua itu bergantung dari sudut mana sang apresiator (manusia) itu memandang sebuah karya sastra.

Di zaman saat ini, kajian sastra memiliki kontribusi dalam dunia pendidikan. bentuk kontribusinya berupa pola-pola kebudayaan yang telah terbentuk, sejarah-sejarah yang sudah terjadi dan didokumentasikan melalui karya sastra, apsek sosial yang ada dalam karya sastra. Hal itu semua karena karya sastra dalam menjawab segala problematika yang ada di sekitar kita.

Kita harus mengetahui bahwa sastra berasal dari hasil pengamatan maupun perenungan manusia tentang kejadian atau situasi yang terjadi disekeliling manusia. Namun, sebagai bentuk opini mesti diungkapkan melalui wujud real dari akibat pengalaman batin. Sastra merupakan sebuah proses yang panjang melalui penyaringan informasi yang ada di sekitar manusia dan dibingkai melalui olah rasa, olah pikir sehingga mengandung nilai estetika yang sangat tinggi untuk dinikmati masyarakat luas.

Jika diamati, saat ini proses pengajaran sastra dirasa belum mendapatkan hasil yang maksimal. Khususnya dalam perspektif kerativitas dan humanitasnya. Padahal aspek yang terpenting dan selalu diperlukan dalam membuat sastra adalah kreativitas, baik sebagai pencipta karya sastra maupun dalam hal pengapresiasi sastra selaku penikmat karya sastra secara nyata.

Dalam hal menyukseskan proses pengajaran, tidak lepas peran penting seorang guru. Hal ini sangat diperlukan dalam menciptakan model pembelajaran sastra yang furturistik dan sesuai keadaan zamannya. Seorang guru selayaknya mengetahui secara tepat kahikat sastra dalam perspektif pengajaran di bangku sekolah.

\section{KAJIAN TEORETIS}

Sebagian kita mengetahui istilah textbook sebagai buku pelajaran. Buku pelajaran sendiri berbagai ahlimenjabrakan bahwa dapat diartikan sebagai bentuk adalah media pembelajaran secara instruksional yang diterapkan dalam proses
Berbicara tentang KTSP 2016 merupakan dasar dari kurikulum 2013. KTSP sendiri biasanya lebih dikenal dengan sebutan kurikulum tingkat satuan pendidikan. Akan tetapi, dalam berjalannya waktu disaat proses pembelajaran, khususnya pengajaran sastra masih belum dapat dimaksimalkan karena bidang sastra diberi waktu yang minim.

Hal ini dikarenakan dalam konsep kurikulum 2013, skema pembelajarannya berbasis teks dan hal ini tidak dapat dipungkiri. Bahwa saat pengajaran sastra lebih banyak berbasis kreativitas dan daya imajinasinya. Jadi bagaimanakah konsep pengajaran atau pembelajaran sastra dalam kurikulum 2013.

Maka dari itu, perlu adanya tinjauan kembali tentang pengajaran sastra yang ada dalam buku teks kurikulum 2013 sehingga terjadi korelasi antara pengajaran bahasa dan pengajaran sastra, terlebih pengajaran sastra yang digunakan dalam buku teks kurikulum 2013 haruslah sesuai dengan konsep pengajaran sastra pada hakikatnya. Peneliti menggunakan konsep moody untuk menelaah tentang buku teks kurikulum 2013. Salah satu model dalam pembelajaran sastra menggunakan model Moody. Model ini dipelopori H.L.N. Moody yang merupakan penggagas konsep ini.

Merujuk latar belakang yang telah diuraikan secara detail di atas. Maka penulis membagi ke dalam beberapa fokus pembahasan. Adapun fokus penelitiannya sebagai berikut:

1. Bagaimana konsep pengajaran sastra dalam buku teks kelas X kurikulum 2013?

2. Bagaimana pengajaran sastra dalam buku teks kelas X kurikulum 2013 ditinjau dari perspektif pengajaran sastra moody?

3. Bagaimana kesesuaian pengajaran sastra dalam buku teks kelas X kurikulum 2013 ditinjau dari perspektif pengajaran sastra moody?

belajar mengajar di dalam kelas. Hal ini sangat dominan atau efektif di dalam kelas. Selain itu, sebagai sarana media penyampaian materi secara efektif dan penyampaian materi dari kurikulum yang telah dicarikan. Beberapa hal ini, merupakan 
aspek penting dalam sistem pendidikan (Rusyana, 1984).

Para siswa dalam memahami dan belajar perlu adanya sebuah alat, alat tersebut tidak lain adalah buku pelajaran. Secara konkret, buku pelajaran menjadi jembatan bagi siswa untuk memahami dan mempelajari segala hal yang ada di dunia ini. Sebagian besar, otak manusia dipengaruhi oleh ilmu-ilmu yang dimilikinya. Ilmu-ilmu tersebut dibingkai dalam buku pelajaran yang acap kali dibaca para siswa di jenjang pendidikan.

Masyarakat belum banyak mengerti bahwa buku pelajaran secara tidak langsung dapat mengubah otak manusia melalui pola pikir di dalam segala aktivitasnya. Oleh karena itu, buku pelajaran seyogyanya disusun secara sistematis, bermutu, dan sesuai dengan kebutuhan serta kompetensi siswa saat ini.

Mengacu pada Permendiknas no. 11 tahun 2005 menjelaskan bahwa di dalam buku teks pelajaran sama seperti buku acuan wajib yang harus digunakan di sekolah dan memuat berbagai sumber materi atau referensi yang dijadikan pedoman atau acuan bagi para siswa dalam mengerjakan tugas pelajaran.

Materi-materi yang disampaikan seorang guru melalui buku teks harus memuat beberapa aspek. Aspek-aspek tersebut guna meningkatkan keimanan dan ketakwaan, budi pekerti dan kepribadian, kemampuan penguasaan ilmu pengetahuan dan teknologi, kepekaan dan kemampuan estetis, potensi fisik dan kesehatan yang disusun berdasarkan standar nasional pendidikan.

Uraian di atas dapat digeneralisasikan bahwa buku pelajaran seyogyanya dijadikan pegangan siswa pada jenjang tertentu sebagai media pembelajaran (instruksional), berkaitan dengan bidang studi tertentu dan sudah memenuhi kebutuhan siswa serta acuan konsep-konsepnya sudah jelas.

Jika mengamati isi dalam buku pelajaran. Buku pelajaran harus standar yang disusun, dirancang dan dievaluasi oleh pakar dalam bidangnya, sehingga meminimalkan kesalahan yang tidak diinginkan, seperti hanya salah konten maupun salah materi yang terkait, biasanya acap kali sudah dilengkapi sarana pembelajaran (seperti kaset rekaman maupun miniatur penunjang materi yang disampaikan).

Buku teks memiliki peranan dan kedudukan yang sangat urgent bagi media pembelajaran, karena buku teks sebagai jembatan untuk pemahaman siswa dalam menyerap ilmu yang disampaikan oleh seorang guru.

Melihat tingkat urgenitas sebuah buku teks pelajaran. Seyogyanya dalam pembuatan buku teks harus sesuai kaidah yang sesuai, sehingga layak dikonsumsi oleh para siswa dalam penunjang pembelajaran.

Mengutip Pusat Perbukuan, 2005. Buku teks pelajaran salah satu fungsinya sebagai tabungan berbagai ilmu pengetahuan yang melengkapi sendi kehidupan umat manusia. Hal ini karena sebuah buku teks pelajaran telah dipersiapkan dari segi kelengkapan dan penyajiannya.

Buku teks pelajaran itu memberikan fasilitas yang lengkap dan dapat juga sebagai pendukung bagi kegiatan belajar mandiri, baik tentang substansinya maupun tentang caranya. Melalui penjabaran tersebut, penggunaan buku teks pelajaran oleh siswa merupakan bagian dari literasi atau keterpahaman akan budaya membaca buku, yang menjadi salah satu tanda dari masyarakat yang maju.

Dipandang dari proses pembelajaran pun demikian. Jika tolok ukur seorang guru dalam perspektif pembelajaran adalah untuk menjadikan siswa memiliki berbagai kompetensi.

Untuk mewujudkannya agar mencapai tolok ukur tersebut, siswa perlu menempuh pengalaman, tugas, pengayaan serta latihan dalam hal mencari informasi. Alat yang paling efektif untuk merealisasikan itu melalui buku teks pelajaran karena pengalaman, tugas, pengayaan serta latihan yang perlu ditempuh dan informasi yang perlu dicari, begitu pula tentang cara menempuh dan mencarinya, disajikan dalam buku teks pelajaran secara terprogram.

\section{Teori Pembelajaran Apresiasi Sastra Menurut Moody}

Perlu kita ketahui, bahwa dalam pembelajaran apresiasi sastra memiliki berbagai model sebagai penunjang kesuksesan tujuan pelajaran. Salah satu model yang perlu diketahui 
oleh para pengajar adalah Model Pembelajaran sastra Moody.

Karya sastra dirasa bagus memiliki beberapa prinsip untuk menjadikan pengajaran apresiasi sastra lebih bermakna. Sastra sebagaipengalaman dan sebagai bahasa.

Sastra sebagai pengalaman memiliki arti bahwa segala hal yang harus dihayati, dinikmati, dirasakan dan dipikirkan oleh manusia. Prinsip ini menjadikan sebuah karya sastra dapat disajikan dalam dunia pendidikan melalui pengajaran apresiasi sastra dan hendaknya pengajaran apresiasi sastra menyajikan pengalaman baru sehingga memberikan wawasan bagi para siswa, (Moody, 1971). Oleh karena itu, seyogyanya sebuah karya sastra harus memberikan pengaruh kepada kehidupan para siswa. Hal yang terutama harus dilakukan guru yang mengampu pelajaran bahasa dan khususnya kesusastraan.

Guru harus memberikan bimbingan agar para siswa menemukan makna mereka sendiri tentang hakikat sebuah karya sastra. Guru harus memiliki sikap pasif namun bijaksana. Maksudnya, sebagai seorang guru tidak serta merta memberikan tugas kepada siswa atau bahkan seorang guru selalu mengarahkan seorang siswa agar sesuai dengan kehendaknya. Namun, yang harus dipahami seorang guru, haruslah bijaksana. Maksud dari bijaksana ini mengetahui waktu maupun porsi seorang guru. Hal ini bermaksud untuk menjadikan pembelajaran apresiasi sastra lebih maksimal.

Melalui prinsip ganda di atas. Dalam pembelajaran apresiasi sastra melalui model Moody, terdapat beberapa tahapan untuk menjadikan model tersebut menjadi nyata dan mudah dipahami oleh seorang guru beserta siswa. Menurut Moody (1971) pembelajaran apresiasi sastra mengikuti penahapan berikut.

1. pelacakan pendahuluan;

2. penentuan sikap praktis;

3. introduksi;

4. penyajian;

5. diskusi; dan

6. pengukuhan.

Enam tahapan tersebut dapat dijadikan pedoman dalam pembelajaran apresiasi sastra model Moody. Adapun penjabarannya sebagai berikut.

\section{Tabel 1. Enam Tahapan Pembelajaran Sastra Berbasis Moody}

\begin{tabular}{ll}
\hline $\begin{array}{c}\text { Tahapan } \\
\text { Pelacakan Pendahuluan }\end{array}$ & $\begin{array}{l}\text { Rincian } \\
\text { Gertujuan untuk membuat strategi yang tepat serta dapat menentukan hal-hal apa saja } \\
\text { yang perlu diperhatikan dan dibutuhkan sebagai sara penunjang pelajaran. }\end{array}$ \\
Penentuan Sikap Praktis & $\begin{array}{l}\text { Guru menentukan aspek apa saja yang berkenaan dengan pelaksanaan penyajian } \\
\text { pembelajaran apresiasi sastra. }\end{array}$ \\
& $\begin{array}{l}\text { Selain itu, di tahap ini, guru harus menentukan karya sastra mana yang akan } \\
\text { disajikan. }\end{array}$ \\
Introduksi & Guru memberikan, informasi awal berupa gambaran tentang karya yang disajikan \\
Pengantar. & kepada siswa, termasuk juga informasi mengenai pengarangnya dan karya \\
& pengarangnya yang lain. \\
& Harap jangan Anda lupakan situasi dan kondisi saat suatu karya sastra diciptakan. \\
& Guru harus meyakini terlebih dahulu hakikat sastra yang bersifat lisan, khususnya \\
Penyajian & puisi. \\
& Guru memberikan kesempatan kepada siswa untuk memberikan argumentasinya \\
& terhadap pembelajaran yang sudah berlangsung. \\
Diskusi & Memberikan tambahan informasi atau pemahaman kepada siswa terhadap karya \\
sastra yang telah dipelajari. & Pengukuhan ini, sama halnya seperti apresiasi pemahaman baik secara lisan maupun \\
tertulis.
\end{tabular}




\section{METODE PENELITIAN}

Pendekatan yang digunakan dalam penelitian ini adalah pendekatan deskriptif. Penelitian deskriptif adalah penelitian yang dimaksudkan untuk menyelidiki keadaan, kondisi, atau hal-hal lain yang sudah disebutkan yang hasilnya dipaparkan dalam bentuk laporan penelitian (Arikunto, 2010:3). Pendekatan ini digunakan sesuai dengan tujuan yaitu untuk melaporkan keadaan objek yang diteliti sesuai dengan apa adanya, yaitu menggambarkan atau

\section{HASIL DAN PEMBAHASAN}

\section{Konsep pengajaran sastra dalam Buku Teks} Kelas X Kurikulum 2013

Konsep yang ditawarkan untuk pengajaran sastra dalam buku teks kelas X kurikulum 2013 merupakan introduksi, penyajian, dan diskusi. Dalam tiga aspek tersebut peneliti berasumsi bahwa tiga aspek tersebut dianggap oleh penulis buku teks telah mewakili semua aspek yang dibutuhkan oleh siswa. Namun, apakah benar dalam ketiga aspek tersebut telah mewakili semua komponen. Maka dari itu peneliti akan membahas satu persatu;

\section{a. Introduksi}

Tujuan introduksi atau pengantar ini untuk memberikan pemahaman awal bagi siswa dalam melaksanakan pembelajaran apresiasi sastra. Guru akan memberikan kisi-kisi atau poin-poin penting dalam pembelajaran.

Guru harus paham akan materi yang disampaikan, sekaligus isi karya sastra sebagai bahan materi pelajaran. Misalnya, ketika kita akan menyajikan cerita pendek "Robohnya Surau Kami" karya A.A. Navis, kita berbicara tentang masyarakat suatu daerah beserta budaya dan tradisinya.

Nah, untuk konsep introduksi dalam buku teks kurikulum 2013 untuk kelas X dalam dilihat dalam kutipan sebagai berikut:

Tugas 5 Memahami Prosedur Membaca Puisi

Tugas yang kalian hadapi di sini agak berbeda dengan tugas-tugas sebelumnya meskipun masih berkaitan dengan prosedur. Kalian akan diajak untuk mendeskripsikan kesesuaian materi pengajaran sastra dalam buku teks kelas X kurikulum 2013: perspektif pengajaran sastra moody. Sumber data pada penelitian ini adalah buku teks pelajaran bahasa Indonesia untuk SMA kelas X kurikulum 2013 terbitan Erlangga. Identitas buku yang dijadikan sumber penelitian adalah sebagai berikut. Judul Buku "Bahasa Indonesia Ekspresi Diri dan Akademik Kelas X”

menerapkan prinsip-prinsip membaca ekspresif pada saat membaca puisi. Untuk itu, ikutilah petunjuk yang diberikan pada setiap nomor!(...). (Buku Teks K 13, 2013: 64)

Berdasarkan kutipan data di atas, seorang guru harus membuka topik atau pembahasan agar siswa memahami secara tepat sesuai kompetensi dasar dan kompetensi inti dalam mata pelajaran yang sedang diajarkan.

Dapat kita pahami bahwa dalam tahap ini merupakan salah satu tahapan pembuka pelajaran yang harus dilakukan semua guru. Seorang guru harus dapat membawa siswa untuk dapat menikmati, menjiwai serta memahami karya sastra yang akan dihadapinya. Pada tahap ini guru memberikan pengantar ringkas berkenaan dengan materi yang akan diterima oleh siswa.

(2) Semua prinsip itu berguna untuk membaca puisi secara ekspresif. Tahukah kalian yang dimaksud dengan membaca ekspresif? Istilah ekspresif diperoleh dari fungsi bahasa secara umum.(...). (Buku Teks K 13, 2013: 66)

Hal yang sama ditujukan oleh kutipan data di atas, bahwa dalam buku teks kurikulum 2013 kelas $\mathrm{X}$ tersebut memiliki introduksi yang jelas, sebelum pembelajaran dimulai, guru terlebih dahulu menjelaskan bagaimana dan apa yang akan dikerjakan pada pertemuan kali ini, penjelasan pendahuluan diharapkan dapat 
menjadikan siswa cepat menangkap apa materi yang akan dijelaskan oleh guru. Hal itu dilakukan dengan cara memberi pengantar terlebih dahulu sebelum siswa dihadapkan langsung kepada teks yang akan dipelajarinya. Pengantar ini dilakukan untuk menarik perhatian dan mengondisikan siswa untuk memasuki tahap penyajian teks (karya sastra). Dalam memberikan pengantar, guru dituntut untuk dapat memahami berbagai kondisi berkaitan dengan pemelajaran yang akan dilaksanakan.

Hal-hal yang harus disampaikan pada tahap ini ialah sesuatu yang berhubungan dengan teks, seperti isu-isu khidupan nyata yang mirip dengan teks, kehidupan pengarang, keadaan masyarakat, dan lain-lain. Kegiatan tersebut merupakan pengondisian agar siswa betul-betul memahami apa yang akan mereka kerjakan dalam pemelajaran. Biasanya pengantar ini yang paling efektif adalah dengan cara mengungkapkan relevansi karya sastra dengan kehidupan siswa. Pola seperti ini dapat dilakukan dengan cara mencari celah sekecil apa pun dalam karya sastra ada sisi keterhubungan antara teks dengan penbaglaman kehidupan nyata siswa. jika ini dapat ditemukan pembelajaran sastra akan semakin mudah karena siswa mendapatkan gambaran langsung yang menyentuh pribadinya.

\section{b. Penyajian}

Tahap penyajian, Pada tahap ini kita sebagai guru harus meyakini terlebih dahulu hakikat sastra yang bersifat lisan, khususnya puisi. Pada tahap ini, khususnya puisi lebih baik dibacakan dulu secara nyaring. Pembaca puisi tidak mesti selalu guru, tetapi bisa saja para siswa sendiri. Dalam buku teks kurikulum 2013 terdapat aspek penyajian, adapun aspek penyajian dalam buku teks kurikulum 2013 sebagai berikut:

(6) Setelah kalian memahami teknik membaca puisi di atas, praktikkanlah teknik itu untuk membaca puisi yang berjudul "Aku" tersebut di depan kelas. Anggaplah bahwa posisi depan kelas itu sebagai pentas. Kalian dapat membaca dengan teknik tersebut secara bergantian satu demi satu dan teman-teman kalian yang lain dapat memberikan komentar atau penilaian (...). (Buku Teks K 13, 2013: 68 )

Berdasarkan kutipan data tersebut, dapat dijelaskan bahwa setelah siswa diberikan introduksi atau pendahuluan, siswa diberi tugas untuk penyajian materi yang telah dijelaskan oleh guru. Dalam hal ini penyajian puisi yang diharapkan dalam materi tersebut.

(3) Dengan keterangan itu, kalian dapat menggarisbawahi bahwa membaca ekspresif sangat cocok diterapkan dalam membaca puisi. Oleh karena itu, sekarang bacalah puisi yang berjudul "Aku", (...).

(Buku Teks K 13, 2013: 68)

Sama halnya dengan kutipan data sebelumnya, kutipan data di atas mendeskripsikan tentang aspek kegiatan penyajian yang dilakukan oleh siswa. Siswa diarahkan untuk menerapkan membaca puisi dengan cara-cara yang telah dijelaskan sebelumnya. Peneliti berasumsi bahwa tujuan dalam penyajian kali ini untuk mengetahui kemampuan dari setiap siswa akan menerapkan materi tersebut. Begitu juga dengan kutipan data di bawah ini, siswa diajak untuk membuat hasil karya dari materi yang telah dijelaskan sebelumnya. Adapun kutipan datanya sebagai berikut:

(9) Mengingat teknik membaca puisi itu dapat diubah-ubah, buatlah teks prosedur yang bersifat protokol tentang hal yang sama menurut pendapat kalian sendiri... (Buku Teks K 13, 2013: 68)

Berdasarkan kutipan data di atas, dapat kita lihat bahwa penyajian yang diberikan oleh seorang guru kepada siswanya haruslah sesuai sehingga porsi yang didapatkan atau yang diperoleh siswa dapat sesuai. Data di atas menunjukkan bahwa cara penyajiannya sudah sesuai karena sebelum siswa diberikan tugas, terlebih dahulu seorang guru mengingatkan materi yang sebelumnya. Kemudian barulah guru 
menyampaikan tugas atau instruksi bagi siswa untuk mengerjakan tugas tersebut.

\section{c. Diskusi}

Pada tahap ini, ranah seorang siswa untuk mengungkapkan berbagai gagasan yang diterimanya selama masa pembelajaran apresiasi sastra. Adu argumen antar siswa yang dipandu seorang guru akan menghasilkan output yang luar biasa untuk keberhasilan seorang siswa dalam mencerna materi yang sudah disampaikan. Sebagai contoh, kutipan di bawah ini.

Diskusikanlah prinsip-prinsip tersebut dengan teman-teman kalian.Setelahitu, praktikkanlah untuk membaca puisi yang berjudul " $A k u$ ". (Buku Teks K 13, 2013: 67)

Berdasarkan kutipan data di atas, seorang siswa akan diajak untuk berdiskusi ketika telah menyelesaikan tahap introduksi dan penyajian. Tahap terakhir ini bertujuan untuk mengevaluasi terhadap pemahaman siswa serta mengukur keaktifan keterampilan bertanya dan menyawab. Dalam tahap diskusi ini, ketika siswa telah diajak berdiskusi dan mendapatkan solusi dari apa yang dihadapinya, selanjutnya siswa disuruh untuk mempraktikkan apa yang telah dibahas dalam diskusi tersebut dan sesuai dengan materi yang diajarkan. Adapun kutipan datanya sebagai berikut:

(4) Bagaimana perasaan kalian setelah membaca kembali puisi tersebut? Siapakah yang dimaksud dengan "aku" pada puisi itu?...(Buku Teks K 13, 2013: 67)

Berdasarkan data di atas, dapat kita cermati bahwa tahap diskusi tersebut berisi tentang pertanyaan dari seorang guru terhadap respons atau komentar yang dialami seorang siswa. Dalam data di atas, interaksi antara guru dan siswa harus tetap terjalin utnuk terjadinya pembelajaran yang produktif. Ketika seorang guru memberikan bahan diskusi kepada siswa, siswa tersebut akan ikut berperan aktif dalam pembelajaran berlangsung. Ada kutipan data yang memperkuat penjelasan tentang aspek atau tahap diskusi dalam buku teks. Adapun kutipan datanya sebagai berikut:

...Diskusikanlah apakah teman-teman kalian juga berpendapat demikian. (Buku Teks K 13, 2013: 68)

Berdasarkan kutipan data di atas, dapat kita lihat bahwa siswa diajak untuk memberikan komentar terhadap materi yang telah disampaikan. Dari komentar-komentar tersebut, siswa diajak untuk berdiskusi dengan teman sejawatnya. Apakah dari komentar-komentar tersebut perlu ditambahkan atau dikurangi. Berdasarkan hasil diskusi tersebut, seluruh siswa diajak untuk memberikan komentar terhadap diskusi yang telah dilakukan oleh teman sejawatnya.

Dapat kita simpulkan dari tiga aspek tersebut meliputi Introduksi, Penyajian, dan Diskusi. Aspek-aspek tersebut ada dalam buku teks.Peneliti berasumsi bahwa konsep yang dipakai oleh penulis buku tersebut sebagai berikut.

Berdasarkan skema konsep pembelajaran sastra, pertama di dalamterdapat dua objek yaitu guru dan siswa. Guru berperan mentransfer ilmu kepada siswa sedangkan siswa sebagai objek untuk menerima ilmu yang diberikan seorang guru. Di awal pembelajaran sastra, seorang guru mengintroduksi materi sehingga siswa dapat memahami materi lebih mudah. Setelah guru mengintroduksi materi, barulah guru menyajikan materi tersebut kepada siswa. Ketika siswa sedang menerima materi dari seorang guru, pastilah ada pertanyaanpertanyaan yang masih ada dibenak mereka. Dari pertanyaan- pertanyaan tersebut, barulah siswa mendiskusikan materi beserta pertanyaanpertanyaan kepada teman sejawatnya. Dari hasil diskusi tersebut siswa dapat menangkap ide pokok dari materi yang diajarkan.

Pengajaran sastra dalam Buku Teks Kelas X Kurikulum 2013 ditinjau dari perspektif pengajaran sastra Moody

Pengajaran sastra dalam buku teks ini agaknya berbeda dengan konsep yang 
ditawarkan dalam bukunya yang berjudul The Teaching of Literature ditulis oleh H. L. B. Moody. Ia mengajukan prinsip bahwa siswa harus mengalami langsung dalam berhubungan dengan karya sastra. Guru tidak boleh menjadi perantara pengalaman tersebut, melainkan harus berperan sebagai fasilitator siswa dalam menentukan pengalaman sastranya.

Selain itu, ia mengemukakan bahwa pengajaran sastra tidak diperkenankan melupakan aspek bahasa karena sastra merupakan seni kreatif yang menjadikan bahasa sebagai mediumnya. Pendekatan yang digunkan model moody dalam pemelajaran sastra adalah pendekatan struktural. Pendekatan ini mengutamakan penyelidikan sastra berdasarkan kenyataan teks karya sastra itu sendiri. Hal ini mengisyaratkan bahwa karya sastra merupakan bentuk seni kreatif yang mempunyai struktur berupa teks-teks. Dengan demikian model Moody masih dapat digunakan untuk menafsirkan karya-karya sastra berdasarkan struktur yang ada.

Namun dalam buku teks kelas $\mathrm{X}$ kurikulum 2013 terutama tentang pengajaran sastra menduplikat dari konsep pengajaran sastra yang dikemukakan oleh Moody. Dalam pemelajaran sastra (Moody, 1971: 26) menyarankan sebuah prosedur yang terdiri atas beberapa tahap. Tahap-tahap tersebut yaitu: (1) Pelacakan Pedahuluan (Prelemenary Assesment), (2) Penentuan Sikap (Practical Decisions), (3) Introduksi (Introductin of work), (4) Penyajian (Presentation of the work), (5) Diskusi (Discussion), (6) Pengukuhan (reinforcement). Akan tetapi berbeda dengan konsep yang ditawarkan dalam buku teks kelas X kurikulum 2013. Memang benar dalam buku teks tersebut telah dirancang sedemikian rupa. Namun konsep

\section{SIMPULAN DAN REKOMENDASI}

Pengajaran sastra dalam buku teks kelas X kurikulum 2013: perspektif pengajaran sastra moody belum sesuai dengan konsep yang ditawarkan oleh Moody tentang model pengajaran sastra, padahal konsep yang digunakan dalam pengajaran sastra di dalam buku teks kelas $\mathrm{X}$ kurikulum 2013 merupakan model pengajaran yang dipakai dalam buku teks tersebut merupakan konsep yang dikemukakan oleh Moody, hanya saja dalam buku teks ini hanya tiga (3) tahap yang dipakai dalam pengajaran sastra. Adapun tahapnya sebagai berikut: (1) Intoduksi, (2) Penyajian, dan (3) Diskusi. Bila ingin mencermati contoh-contoh tahap yang dipakai dalam buku teks kelas $\mathrm{X}$ kurikulum 2013, dapat dilihat dalam analisis di atas.

\section{Kesesuaian pengajaran sastra dalam Buku Teks Kelas X Kurikulum 2013 ditinjau dari perspektif pengajaran sastra Moody}

Kesesuaian pengajaran sastra dalam buku teks kelas X kurikulum 2013 ditinjau dalam perspektif pengajaran sastra moody agaknya kurang menyeluruh, padahal yang digunakan dalam pengajaran sastra di buku teks kelas X kurikulum 2013 merupakan model pengajaran sastra moody. Marilah kita lihat kedua konsep pengajaran sastra dari kacamata model moody maupun yang ada di buku teks tersebut. Berdasarkan pembahasan di atas, dapat disimpulkan bahwa kesesuaian pengajaran sastra dalam buku teks kelas X kurikulum 2013: perspektif pengajaran sastra moody belum sesuai dengan konsep yang ditawarkan oleh Moody tentang model pengajaran sastra, padahal konsep yang digunakan dalam pengajaran sastra di dalam buku teks kelas X kurikulum 2013 merupakan model pengajaran sastra yang dikembangkan oleh Moody, meliputi: pelacakan pendahuluan, penentuan sikap praktis, introduksi, penyajian, diskusi, dan pengukuhan. Sedangkan yang digunakan dalam buku teks kelas X kurikulum 2013 hanya tiga aspek yang dimiliki Moody, meliputi: introduksi, penyajian, dan diskusi. 
Diharapkan penelitian ini dapat ditindaklanjuti dalam proses pembelajaran. Pembelajaran sastra yang menggunakan metode moody merupakan salah satu alternatif bagi pengajar sastra, khususnya bagi anak sekolah dasar, karena masa-masa anak yang menempuh

\section{DAFTAR PUSTAKA}

Moody, H. L. B. (1971). Longman Handbooks for Language Teachers. The Teaching of Literature. London: Longman Group Ltd.

Moody, H. L. B. (1974). The Teaching of Literatur. London: Longman Group Ltd.

Rusyana, Y. (1983). Metode Pengajaran Sastra. Bandung: Gunung Larang.

Segers, R. T. (2000). Evaluasi Teks Sastra. Diterjemahkan oleh Suminto A. Sayuti. Yogyakarta: Adi Cinta.

Silberstein, S. (1994). Techniques and Resources in Teaching Reading. New York: Oxford University Press.

Syahrial. (2007). "Tentang Pengajaran Sastra Lama di Sekolah". Makalah pada Seminar Bahasa dan Sastra di Fakultas Ilmu Pengetahuan Budaya UI, Depok.

Tarigan, H. G. (1984). Prinsip-Prinsip Dasar Sastra. Bandung: Angkasa.

Teeuw, A. (1983). Membaca dan Menilai Sastra. Jakarta : Gramedia. pendidikan di jenjang sekolah dasar perlu metode yang mengasyikkan agar dapat menikmati hakikat karya sastra dalam perspektif pendidikan. Selain bagi para siswa, metode ini juga dapat membantu para guru dalam proses belajar mengajar, khususnta dalam pembelajaran sastra.

Teeuw, A. (1988). Sastra dan Ilmu Sastra.Jakarta : Pustaka Jaya Girimukti Pustaka.

Teeuw. A. (1988). Sastra dan Ilmu Sastra: Pengantar Teori Sastra. Jakarta: Pustaka Jaya.

Thomas and Robinson. (1986). Improving Reading in Every Class. Boston: Allyn and Bacon.

Tierney, R.J. et.al. (1991). Portofolio Assessment in the Reading-Writing Classroom. Norwood: Christoper-Gordon Publishers.

Tierney, R.J. et.al. (1995). Reading Strategies and Practices. Boston: Allyn and Bacon.

Valdes, M.J. (1987). Phenomenological Hermeneutical Hermeneutics and the Study of Literature. London: University of Toronto Press.

Wellek, R. dan Warren, A. (1956). Theory of Literature. New York: Harcout, Barance and Company. 